\title{
Pemetaan Daya Dukung Lingkungan Berbasis Jasa Ekosistem Penyedia Pangan dan Air Bersih di Kota Pekalongan
}

\author{
Erik Febriarta 1,3, dan Roza Oktama²
}

\author{
${ }^{1}$ Magister Pengelolaan Pesisir dan Daerah Aliran Sungai, Fakultas Geografi, Universitas Gadjah Mada, Yogyakarta; \\ e-mail: e.febriarta@gmail.com \\ 2 Program Studi Ilmu Lingkungan, Pasca Sarjana, Universitas Gadjah Mada, Yogyakarta \\ 3 Palawa Karya, Yogyakarta
}

\begin{abstract}
ABSTRAK
Identifikasi spaisal sumber daya alam merupakan salah satu pendekatan untuk mengetahui kapasitas sumber daya terhadap perubahan lahan laju pertumbuhan di suatu wilayah. Kota Pekalongan merupakan kota yang berada di pesisir utara Pulau Jawa yang mempunyai isu lingkungan berkurangnya ruang sumber daya lahan dikarenakan aktivitas pertumbuhan permukiman dan lahan terbangun. Selain itu mempunyai isu lingkungan menurunnya ketersediaan air. Tujuan dari penelitian ini adalah mengetahui daya dukung dan daya tampung lingkungan hidup di Kota pekalongan dari sektor penyedia yaitu ketahanan pangan dan air bersih. Daya dukung dan daya tampung dengan berbasis jasa ekosistem mempunyai karakteristik yang lebih mencerminkan kondisi lingkungan dengan pendekatan ekoregion, yaitu pendekatan geomorfologi lingkungan dan kondisi eksisting dari penggunaan lahan. Hasil penelitian menunjukkan kelas daya dukung hidup penyedia pangan di Kota Pekalongan secara umum rendah $47,11 \%$, sedangkan kelas daya dukung dan daya tampung lingkungan hidup untuk air bersih secara umum adalah sedang $74,22 \%$.
\end{abstract}

Kata kunci: Daya dukung, jasa ekosistem, sistem informasi geografis (SIG)

\begin{abstract}
Spatial identification of natural resources is one approach to determine their capacity to deal with land-use conversion and regional growth rates. Pekalongan, a city on the north coast of Java Island, Indonesia, has been faced with environmental issues as the growth of settlements and built-up land continues to reduce land resources and water availability. This study was conducted to assess the carrying and environmental capacities of the city's supply sector, i.e., food security and clean water. Ecosystem services have characteristics that better reflect both capacities through the ecoregional perspective, which incorporates an environmental geomorphological approach and existing land-use condition. The results showed that the carrying capacity of food providers in Pekalongan were generally low $(47.11 \%)$, while those of clean water were moderate $(74.22 \%)$.
\end{abstract}

Keywords: carrying capacity, ecosystem service, geographic information system (GIS)

Citation: Febriarta, E., dan Oktama, R. (2020). Pemetaan Daya Dukung Lingkungan Berbasis Jasa Ekosistem Penyedia Pangan dan Air Bersih di Kota Pekalongan. Jurnal Ilmu Lingkungan, 18(2), 283-289, doi:10.14710/jil.18.2.283-289

\section{Pendahuluan}

Definisi sumber daya alam mengacu undangundang nomor 32 tahun 2009 tentang perlindungan dan pengelolaan lingkungan hidup adalah unsur lingkungan hidup yang terdiri atas sumber daya hayati dan non hayati yang secara keseluruhan membentuk kesatuan ekosistem (UU No.32 Tahun 2009, bab I, pasal 1, ayat 9). Sumber daya merupakan komponen penting dalam keberlangsungan manusia dan kehidupan makhluk hidup disekitarnya. Semakin tinggi populasi makhluk hidup maka semakin banyak sumber daya yang dimanfaatkan untuk keberlangsungan, sehingga menimbulkan peningkatan pemanfaatan ruang aktivtas (Muta'ali, 2015). Peningkatan aktivitas manusia dan makhluk hidup lainnya mepmpunyai dampak dari sisi ketersediaan sumber daya antara lain, berkurangnya sumber daya atau menurunya kuantitas lingkungan dan menurunnya kualitas lingkungan (Santosa, 2010; $\mathrm{KLH}, 2014$ ). Penurunan tersebut sangat dipengaruhi oleh perubahan fungsi lahan dari kondisi alami atau dampak dari alih guna lahan (Santosa, 2010; Muta'ali, 2015).

Perubahan ruang dan pertumbuhan ekonomi sejalan dengan perkembangan pembangunan daerah maupun rencana jangka panjang dari pemerintah, yang mempunyai tujuan untuk mendukung aktivitas manusia dan makhluk hidup disekitarnya dengan mempertimbangkan aspek keberlangsungan lingkungan dimasa yang akan datang (Sumadyanti 
dkk, 2016). Untuk mewujudkan keseimbangan tersebut dimana ketersediaan alam atau sumber daya alam dapat dimanfaatkan dengan optimal dan mampu berkelanjutan perlu dipantau kesimbanganya dengan menghitung perbandingan nilai kapasitas dan pemanfaatan (MEA, 2005; Santosa, 2010). Parameter pemanfaatan sumber daya alam secara fisik mempunyai keterbatasan untuk diolah dan dimanfaatkan (KLH, 2014). Dampak penurunan kualitas dan kuantitas lingkungan dapat mengakibatkan bencana disuatu wilayah, sehingga untuk menjaga kesimbangan tersebut perlu mempertimbangan aspek kemampuan daya dukung dan daya tampung suatu wilayah (MEA, 2005; Santosa, 2010; Muta'ali, 2015).

Amanah perlindungan dan pengelolaan lingkungan hidup tertuang di dalam undang-undang nomor 32 tahun 2009, dalam bab I, pasal 1, ayat 2 . Penjelasan dari undang-undang tersebut menjelaskan pentingnya potensi lingkungan dan pentingnya melestarikan fungsi lingkungan hidup dan mencegah terjadinya pencemaran dan atau kerusakan lingkungan yang meliputi perencanaan, pemanfaatan, pengendalian, pemeliharaan, pengawasan secara berkelanjutan (UU No.32 Tahun 2009). Dalam pengelolaan sumber daya alam secara berkelanjutan perlu dikaji tentang kebutuhan dasar untuk manusia dan makhluk hidup dilingkungan sekitar, dengan memenuhi aspek kesejahteraan sosial ekonomi (KLH, 2014; MEA, 2005; Sabila, 2020; Sumadyanti dkk, 2016). Perlunya perencanaan dalam menyususn daya dukung dan daya tampung dalam pengelolaan lingkungan hidup dapat memberikan peroyeksi kemampuan lingkunagn dengan mewujudkan pembangunan yang berkelenjutan (DLH Kota Pekalongan, 2018; KLH, 2014; P3EJ, 2017; Muta'ali 2015).

Pendekatan konsep daya dukung dan daya tampung lingkungan merupakan amanat udanganundang yang ditertuang dalam undang nomor 32 tahun 2009. Pendekatan yang merepresentasikan kondisi wilayah dapat dilakukan dengan perhitungan dengan jasa ekosistem (KLH, 2014; P3EJ, 2017; Santosa, 2010; Muta'ali, 2015). Manfaat teridentifikasinya daya dukung dan daya tampung lingkungan hidup berbasis jasa ekosistem diantaranya: sebagai panduan bagi pemerintah pusat khususnya dalam kaitannya dengan pelaksanaan rencana pembangunan, dan sebagai pedoman bagi setiap pemerintah daerah dalam rangka perlindungan dan pengelolaan sumberdaya alam dan lingkungan hidup, serta perumusan kebijakan program pembangunan daerah berbasis daya dukung dan daya tampung lingkungan hidup, dengan memkasimalkan potensi sumberdaya alam secara menyeluruh dan berkelanjutan (DLH Kota Pekalongan, 2018; P3EJ, 2017; Muta'ali 2015; Santosa 2010).

Kota Pekalongan merupakan salah satu kabupaten atau kota di Jawa Tengah yang berada di pesisir dari Laut Jawa dengan isu lingkungan alih fungsi lahan permukiman semakin tinggi dan menurunnya kualitas air (DLH Kota Pekalongan, 2018; IKPLHD Provinsi Jawa Tengah, 2017). Pertumbuhan permukiman dan penggunaan lahan terbangun yang tinggi mengakibatkatan perubahan fungsi lahan. Parameter perubahan atau alih fungsi lingkungan sebagai sumber daya dukung lingkungan parameter yang yang diukur adalah prosentase (\%) keberadaan lahan sawah padi maupun pertanian (P3EJ, 2017; MEA, 2005). Berdasarkan karakteristik gemorfologi lingkungan di Kota Pekalongan merupakan dataran pesisir dengan dominasi pesisir pantai bentukan fluvial atau terbentuk karena proses sungai dan dataran rendah (Gambar 1). Pendekatan daya dukung dan daya tampung lingkungan dengan jasa ekosistem didasarkan atas analisis cross validation data ekoregion dan penggunaan lahan eksisting (PE3ES, 2011;KLH, 2014)

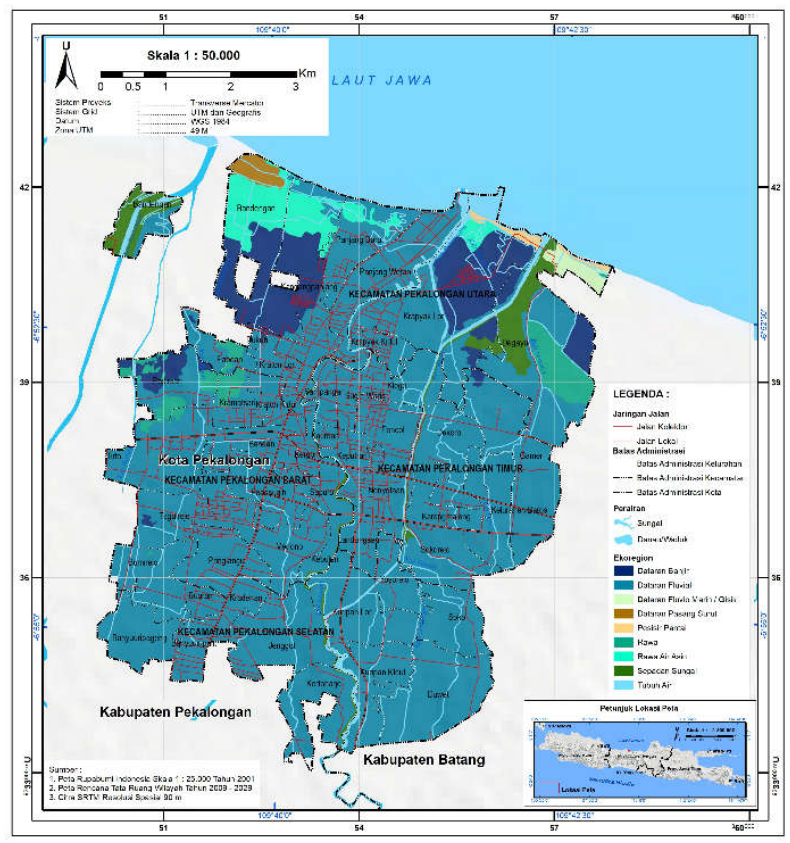

Gambar 1. Ekoregion Kota Pekalongan

Penetapan batas ekoregion dengan mempertimbangkan kesamaan dalam hal: karakteristik bentang alam (natural landscape), daerah aliran sungai, ikilm, flora dan fauna asli, sosial budaya (KLH, 2014). Sebaran keruangan di pesisir dari tiap kategori penutup lahan di Kota Pekalongan menunjukkan pola tersendiri. Penutup lahan berupa bangunan permukiman tersebar di bagian tengah, memanjang dari selatan hingga pesisir di sebelah utara. Penutup lahan berupa bangunan non permukiman dan lahan terbuka mengisi beberapa bagian memanjang di antara ruang bangunan permukiman. Penutup lahan berupa lahan pertanian berada di sisi barat dan timur dari tutupan lahan yang paling dominan di Kota Pekalongan, yakni permukiman. Penutup lahan berupa tambak terkonsentrasi di sebelah utara dari Kota Pekalongan (Gambar 2). 


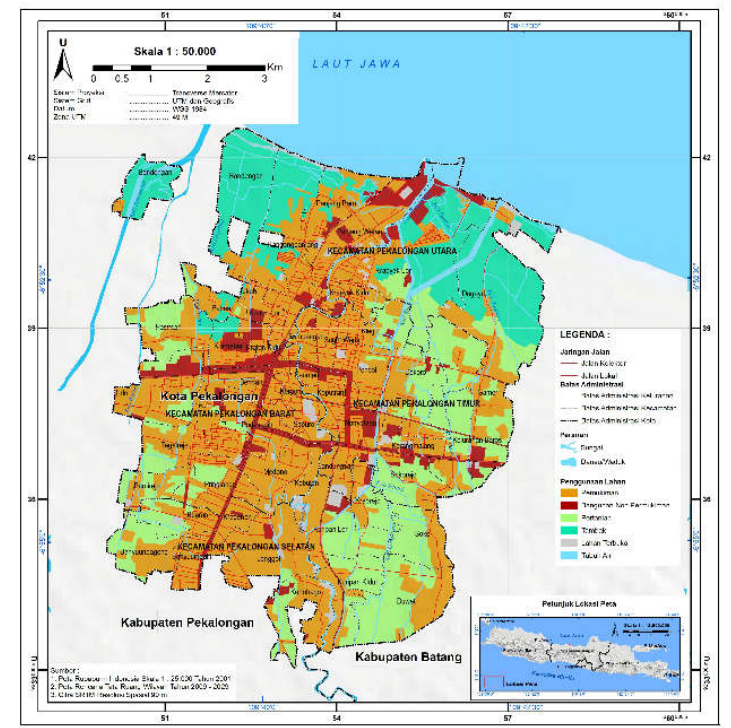

Gambar 2. Penggunaan lahan Kota Pekalongan

Berdasarkan latar belakang tersebut tujuan dari penelitian ini adalah mengetahui kelas daya dukung dan daya tampung lingkungan di Kota Pekalongan. Pendekatan yang digunakan untuk menghitung data dukung lingkungan menggunakan jasa ekosistem penyedia pangan dan air bersih dengan pendekatan geomorfologi (ekoregion) dan penggunaan lahan eksisting. Penyajian kelas daya dukung lingkungan disajikan secara keruangan (spasial) dengan bantuan perangkat lunak Sistem Informasi Geografis (SIG) dengan menggunakan citra world view tahun perekaman tahun 2018.

\section{Metode Penelitian}

\subsection{Penilaian Ekoregion dan Penutup Lahan dengan Valuas Refrensi Standar}

Perhitungan daya daukung lingkungan hidup mengacu ke pedoman penyusunan daya dukung dan daya tampung lingkungan hidup (KLH, 2014). Penilaian ini didasarkan pada valuasi dari refrensi standar yaitu dengan memberikan nilai atau skor terhadap masing-masing jenis penggunaan lahan dan masing-masing bentuklahan satuan ekoregion yang dirumuskan oleh para ahli yaitu geomorfologi, lingkungan dan geologi (P3EJ, 2017; Sumadyanti dkk, 2016). Kemudian dilakukan refrensi standar yaitu atau cross validation setiap dari kondisi yang berbeda. Hasil dari penilian pairwise comparation, hasil valuasi dianalisis dengan Sistem Informasi geografi (SIG).

\subsection{Teknik Analisis Perbandingan Pairwise (Pairwise Comparation)}

Analisis perbandingan didasarkan atas nilai bobot yang telah ditetapkan dengan tingkat prioritas atau pendektan Analytical Hierarchy Process (AHP) (Enrique dan Milagros, 2017). Data yang dibandingkan antara lain koefisien matrik pairwise penutup lahan yaitu nilai yang diperoleh dari analisis matrik pairwise hasil penilaian pakar (metode expert based valuation) terhadap peran tutupan lahan terhadap jenis-jenis jasa ekosistem dan koefisien 285 matrik pairwise ekoregion (Widodo dkk, 2016). Koefisien matrik pairwise ekoregion adalah nilai yang diperoleh dari analisis matrik pairwise hasil penilaian pakar (metode expert based valuation) terhadap peran ekoregion terhadap jenis-jenis jasa ekosistem. (P3EJ, 2015). Hasil dari penilian tersebut jika menunjukkan nilai tinggi koefisien, maka memiliki peranan penting terhadap jasa ekosistem (KLH, 2014).

\subsection{Nilai Indek Jasa Ekosistem (IJE)}

Nilai Indek Jasa Ekosistem (IJE) merupakan nilai indek besar kecil nilai dari jenis-jenis jasa ekosistem berkisar 0-1. Nilai Indek Jasa Ekosistem (IJE) dihitung dengan pembobotan dengan satuan luas area sebagai berikut (KLH, 2014):

IJE i,x $=((\mathrm{KJEi}, \mathrm{a} \times \mathrm{LPa})+(\mathrm{KJE}$ i,b $\mathrm{x} \mathrm{LPb})+(\mathrm{KJE}$ i,c $\mathrm{x}$ dimana:

$$
\text { LPc) }+\cdots(\text { KJE i,n } \times \text { LPn) }) /(\text { LA tot })
$$

IJE $\mathrm{i}, \mathrm{x}=$ nilai indek jasa ekosistem jenis i (misal: pangan) di wilayah $\mathrm{x}$ (misal: kabupaten/ekoregion)

$\mathrm{KJE} \mathrm{i}, \mathrm{x}=$ koefisien jasa ekosistem jenis i (misal : pangan) di polygon a (misal: kabuapten)

$\mathrm{LPa}=$ luas polygon a dengan nilai $\mathrm{KJE} \mathrm{a}$

LA tot = luas polygon total $(\mathrm{km} 2 / \mathrm{m} 2)$

\subsection{Indek Komposit Jasa Ekosistem}

Indek Komposit Jasa Ekosistem adalah nilai gabungan dari indek jenis-jenis jasa ekosistem yang diperoleh dengan cara melakukan perhitungan ratarata (mean). Indek Komposit Jasa Ekosistem dilakukan secara bertingkat pada empat jenis kelompok jasa ekosistem, yaitu kelompok jasa ekosistem penyedia, pengaturan, dan budaya. Rumus seluruh indek nilai jasa ekosistem, diperoleh dengan cara melakukan perhitungan rata-rata, sebagai berikut ( KLH 2014):

IKJE $i, x=(I J E i, x+I J E j, x+I J E k, x+I J E ~ l, x+I J E$ $\mathrm{m}, \mathrm{x}) /\left(\sum \mathrm{IJE}\right)$

dimana:

IKJE $\mathrm{i}, \mathrm{x}=$ nilai indek komposit jasa ekosistem kelompok jasa ekosistem i (penyedia pangan dan airatnah)

IJE $\mathrm{i}, \mathrm{x}=$ indek jasa ekosistem $\mathrm{i}$

$\sum \mathrm{IJE}=$ Jumlah jasa ekosistem (misal: kelompok jasa pendukung=5 IJE)

\subsection{Koefisien Jasa Ekosistem (KJE)}

Koefisien Matrik Pairwise Jasa Ekosistem adalah nilai yang menunjukkan besar kecilnya nilai jasa ekosistem yang diperoleh dari perhitungan perkalian matrik pairwise landcover dan matrik pairwise landcover serta digunakan untuk melakukan pemetaan jenis-jenis jasa ekosistem. Rumus untuk mendapatkan koefisein tersebut, sebagai berikut (KLH, 2014):

$\mathrm{KJE}=$ kec $\mathrm{x}$ klc

dimana:

$\mathrm{kec}=$ koefisien berdasarkan ekoregion 
klc $=$ koefisien berdasarkan penutup lahan

\subsection{Klasifikasi Nilai Koefisien Jasa Ekosisten (KJE)}

Nilai rentang KJE dinormalisasi dengan pendekatan scalling dengan rentang nilai antara 0-1. Nilai semakin mendekati nilai 1, berarti Koefisein Jasa Ekosistem (KJE) suatu wialayah semakin tinggi dan sebaliknya. Setiap nilai jasa ekosistem yang dihasilkan memiliki rentang nilai atau kelas yang berbeda-beda, yang diperoleh dari perbedaan nilai maksimum dan minimum yang beragam. Berdasarkan pedoman penyusunan daya dukung dan daya tampung, nilai KJE dapat diklasifikasikan menjadi 5 tingkat, dengan pendekatan geometrik sebagai berikut (KLH, 2014):

Analisis Spasial Sistem Informasi Geografis (SIG)

$\mathrm{Xn}=\mathrm{B} / \mathrm{A}$

dimana:

$\mathrm{B}=$ nilai maksimuman

$\mathrm{A}=$ nilai minimum

$\mathrm{n}=$ jumlah kelas

\subsection{Analisis Keruangan (Spasial)}

Masing-masing komponen ekoregion dan tutupan lahan tersebut memiliki nilai koefisien tertentu dalam mempengaruhi jasa ekosistem (hasil matrik pairwise comparation). Koefisen dengan nilai semakin besar mempunyai arti mempengaruhi daya dukung lingkungan semakin baik, atau daya dukung lingkungan tinggi. Sedangkan nilai yang semakin kecil atau mendekati 0 , maka nilai tersebut rendah dalam daya dukung lingkungan (KLH, 2014; P3EJ, 2015). Berdasarkan variasi nilai koefisien ekoregion dan tutupan lahan tersebut, dilakukan analisis SIG (Gambar 3) untuk menentukan Koefisien Jasa Ekosistem (KJE).

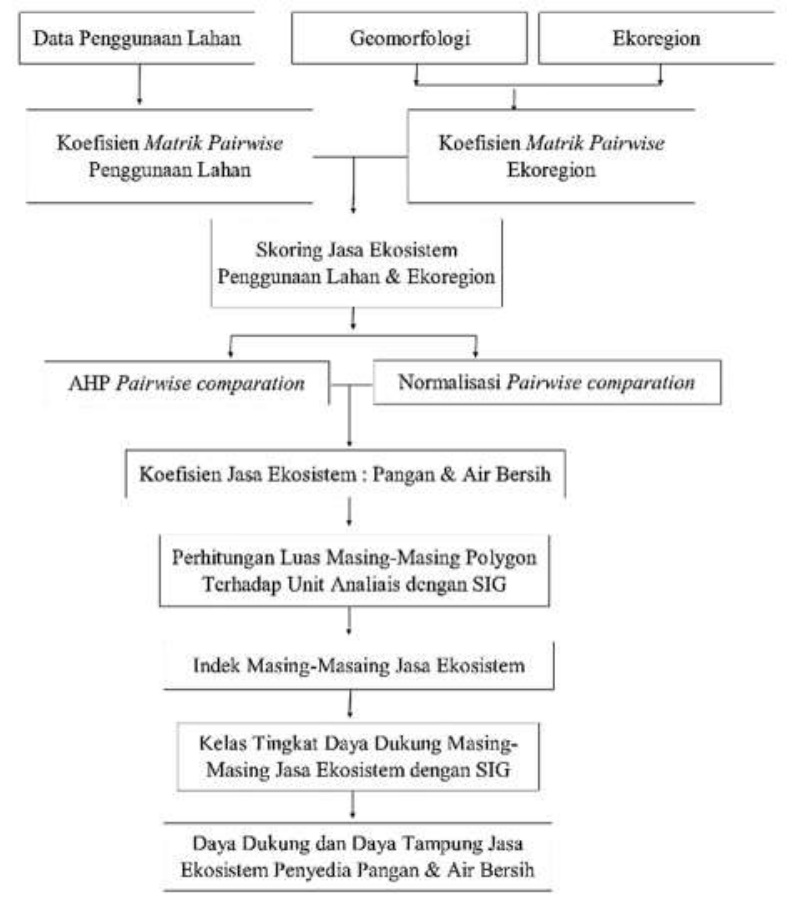

Gambar 3. Metode pemetaan daya dukung lingkungan berbasis jasa ekosistem penyedia pangan dan air bersih di Kota Pekalongan.
Setelah diperoleh koefisisen jasa ekosistem, tahap akhir pemetaan daya dukung adalah pembuatan layout, yaitu proses untuk mengatur data yang digunakan sebagai output, dan bagaimana data tersebut akan ditampilkan. Sistem Informasi Geografis (SIG) dapat menampilkan berbagai macam informasi sebagai hasil akhir dari suatu operasi. Peta daya dukung dan daya tampung lingkungan hidup berbasis jasa ekosistem ditampilkan dalam lima bentuk klasifikasi secara ordinal, mulai dari sangat rendah, rendah, sedang, tinggi, sangat tinggi.

\section{Hasil dan Pembahasan}

\subsection{Daya Dukung dan Daya Tampung Lingkungan Penyedia Pangan}

Pangan merupakan kebutuhan dasar bagi setiap mahluk hidup untuk dapat bertahan hidup, tentu terutama bagi manusia. Ketersediaan pangan merupakan bagian dari ketahanan sumber daya pemenuhan kebutuhan dasar suatu wilayah. Kota Pekalongan memiliki karakteristik lahan tersendiri, mengacu kepada ekoregion dan penutup lahan yang dimiliki. Masing-masing lahan memiliki ciri khas yang berbeda termasuk dalam penyediaan bahan pangan bagi manusia.

Secara garis besar di Kota Pekalongan, lahan yang mampu menyediakan bahan pangan dapat dibagi menjadi lahan berpotensi sangat rendah, rendah, sedang, tinggi, dan sangat tinggi. Jasa Ekosistem Penyediaan Pangan dengan kelas sangat rendah hingga rendah dominan dijumpai di bagian tengah, memanjang dari selatan hingga sebelah utara dari Kota Pekalongan. Luasan tiap kecamatan dalam konteks penyediaan pangan dengan kelas sangat rendah - rendah terdapat di Kelurahan Bendan, Kelurahan Kramatsari, Kelurahan Kraton Kidul, Kelurahan Medono, dan Kelurahan Podosugih yang terletak di Kecamatan Pekalongan Barat. Di Kecamatan Pekalongan Selatan terdapat di Kelurahan Jenggot, Kelurahan Kertoharjo, dan Kelurahan Kuripan Lor. Kecamatan Pekalongan Timur terdapat di Kelurahan Dekoro, Kelurahan Gamer, dan Kelurahan Poncol. Kecamatan Pekalongan Utaara ada pada Kelurahan Bandengan, Kelurahan Panjang Baru, dan Kelurahan Panjang Wetan.

Luasan wilayah Kota Pekalongan dengan kelas jasa penyediaan pangan sangat rendah - rendah adalah mencapai $2.700 \mathrm{Ha}$ atau setara 57,36\% dari luas keseluruhan Kecamatan Pekalongan. Luasan wilayah dengan kelas jasa penyediaan pangan dengan kelas sedang hanya berkisar $8,8 \%$ dari luasan total Kota Pekalongan. Daya dukung lingkungan jasa ekosistem penyedia pangan dengan kelas tergolong tinggi - sangat tinggi di Kota Pekalongan memiliki pola sebaran mengelompok di sisi sebelah timur dari Kota Pekalongan. Sebaran setiap kelurahan per kecamatan untuk penyediaan pangan dengan kelas tinggi - sangat tinggi terdapat di Kelurahan Bumirejo dan Kelurahan Pringlangu untuk Kecamatan 
Pekalongan Barat, Kelurahan Duwen di Kecamatan Pekalongan Selatan, Kelurahan Barus dan Kelurahan Karang Malang di Kecamatan Timur, serta Kelurahan Degayu dan Kelurahan Krapyak Lor di Kecamatan Pekalongan Utara. Wilayah dengan jasa ekosistem penyediaan pangan kelas tinggi - sangat tinggi memiliki luasan dengan kisaran $1.600 \mathrm{Ha}$ atau setara dengan persentase 33\% dari luas keseluruhan Kota Pekalongan. Informasi tiap kelas jasa ekosistem penyediaan pangan disajikan dalam Tabel 1. dan Gambar 4.

Pola sebasan spasial dari jasa ekosistem penyediaan pangan menghadirkan informasi tersendiri. Dominasi luasan dengan daya dukung lingkungan jasa penyediaan pangan kelas rendah sangat rendah di Kota Pekalongan mengindikasikan adanya pengaruh kuat dari dominasi keberadaan penutup lahan berupa bangunan permukiman dan non permukiman di atas Ekoregion Dataran Fluvial. Ekoregion Dataran Fluvial sebetulnya memiliki karakteristik yang sangat memadai untuk kebutuhan penutup lahan yang profuktif untuk komoditi pangan, namun kasus di Kota Pekalongan, Dataran Fluvial lebih diperuntukan untuk bangunan. Kondisi tingginya jumlah penutup lahan berupa bangunan permukiman dan non permukiman di Kota Pekalongan sebandaing dengan tekanan penduduk yang terus meningkat jumlahnya.

Wilayah dengan daya dukung lingkungan jasa penyediaan pangan berkelas tinggi di Kota Pekalongan juga menunjukkan pola tersendiri. Wilayah dengan kelas tinggi dalam jasa penyediaan pangan terkelompok di sisi sebelah timur dari Kota Pekalongan. Sebaran tersebut sesuai dengan keberadaan aliran sungai di sisi timur Kota Pekalongan yang kemudian dianggap menjadi sumber pemenuhan kebutuhan air pertanian. Dari sudut pandang potensi alih fungsi lahan menjadi permukiman, keberadaan penutup lahan pertanian di sebelah timur dari Kota Pekalongan harus dapat dipertahankan luasannya, dalam konteks menjaga neraca keseimbangan produksi pangan di Kota Pekalongan. Wilayah dengan kemampuan jasa penyediaan pangan kelas sedang hingga tinggi juga dijumpai mengelompok di pesisir sebelah utara Kota Pekalongan. Ekoregion Pesisir dan penutup berupa tambak tentu mampu menjadi lahan dengan fungsi produksi pangan yang terbilang baik.

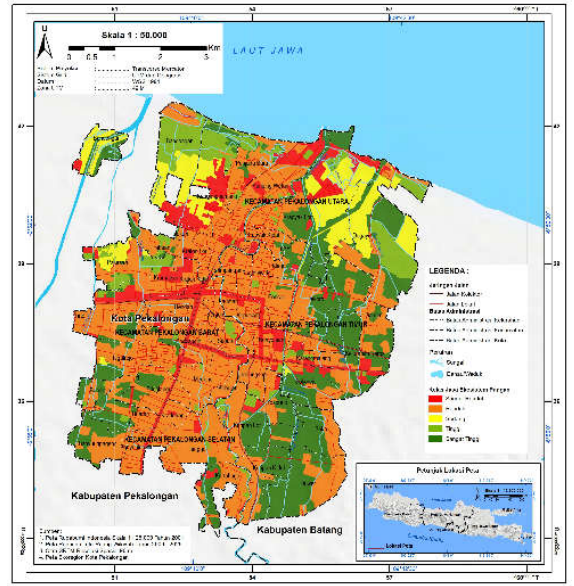

Gambar 4. Kelas daya dukung lingkungan sektor panyedia pangan.

\subsection{Daya Dukung dan Daya Tampung Lingkungan Penyedia Air Bersih}

Karakteristik sebaran ekoregion di Kota Pekalongan akan membawa kepada perbedaan kondisi lingkungan fisik yang tentu berpengaruh pada komponen lingkungan lain baik komponen biotik maupun komponen kultural yang saling berinteraksi di dalamnya. Interaksi antar komponen lingkungan dalam cakupan ekoregion yang bervariasi menghadirkan manfaat tersendiri berupa kemelimpahan sumber daya alam maupun sumber daya hayati. Kemelimpahan sumber daya terutama sumber daya perairan di Kota Pekalongan, kemudian juga dihadapkan dengan permasalahan terkait daya dukung dan daya tampung lingkungan.

Di samping pangan, air juga merupakan kebutuhan utama bagi hidup manusia. Dalam konteks kemanfaatannya, air bersih menjadi kebutuhan yang tak bisa tergantikan oleh komoditas lain. Dari sudut pandang ekologi, air bersih juga merupakan salah satu manfaat yang dapat diperoleh dari fungsi ekosistem. Secara alami, air bersih dapat diperoleh dari air permukaan, seperti: sungai dan danau maupun berasal dari air tanah. Seperti halnya variasi secara spasial pada daya dukung jasa ekosistem penyediaan pangan, jasa ekosistem penyedia air bersih di Kota Pekalongan juga memiliki karakteristik tersendiri, baik pada tingkatan buruk maupun pada tingkatan baik. Lingkungan Kota Pekalongan mampu menyediakan air bersih dengan diferensiasi pada kelas sangat rendah rendah, sedang, tinggi, dan juga sangat tinggi.

Tabel 1. Daya Dukung Berbasis Jasa Ekosistem Penyedia Pangan

\begin{tabular}{|c|c|c|c|c|c|c|c|c|c|c|c|c|}
\hline \multirow{3}{*}{ Kecamatan } & \multicolumn{10}{|c|}{ Kelas Koefisien Jasa Ekosistem Pangan } & \multirow{2}{*}{\multicolumn{2}{|c|}{ Total Luas }} \\
\hline & \multicolumn{2}{|c|}{ Rendah } & \multicolumn{2}{|c|}{ Sangat Rendah $\quad \mathrm{S}$} & \multicolumn{2}{|c|}{ Sangat Tinggi } & \multicolumn{2}{|c|}{ Sedang } & \multirow{2}{*}{$\begin{array}{c}\text { Tinggi } \\
\mathrm{Ha}\end{array}$} & & & \\
\hline & $\mathrm{Ha}$ & $\%$ & $\mathrm{Ha}$ & $\%$ & $\mathrm{Ha}$ & $\%$ & $\mathrm{Ha}$ & $\%$ & & $\%$ & $\mathrm{Ha}$ & $\%$ \\
\hline Pekalongan Barat & 667 & 29,8 & 143 & 29,4 & 119 & 9,6 & 30 & 7,1 & 63 & 17,1 & 1.024 & 21,5 \\
\hline Pekalongan Selatan & 584 & 26,0 & 35 & 7,2 & 463 & 37,4 & 2 & 0,6 & 24 & 6,5 & 1.109 & 23,3 \\
\hline Pekalongan Timur & 506 & 22,6 & 98 & 20,1 & 354 & 28,6 & 10 & 2,3 & 21 & 5,7 & 990 & 20,8 \\
\hline Pekalongan Utara & 481 & 21,4 & 210 & 43,2 & 301 & 24,3 & 377 & 89,8 & 259 & 70,5 & 1.63 & 34,3 \\
\hline Total Luas & 2.240 & 4,1 & 487 & 10,2 & 1.239 & 26,0 & 420 & 8,8 & 368 & 7,7 & 4.756 & 100 \\
\hline
\end{tabular}

Sumber: Analisis, 2020 
Tabel 2. Daya Dukung Berbasisi Jasa Ekosistem Penyedia Air Bersih

\begin{tabular}{|c|c|c|c|c|c|c|c|c|c|c|c|c|}
\hline \multirow{3}{*}{ Kecamatan } & \multicolumn{10}{|c|}{ Kelas Koefisien Jasa Ekosistem Air Bersih } & \multirow{2}{*}{\multicolumn{2}{|c|}{ Total luas }} \\
\hline & \multicolumn{2}{|c|}{ Rendah } & \multicolumn{2}{|c|}{ Sangat Rendah } & \multicolumn{2}{|c|}{ Sedang } & \multicolumn{2}{|c|}{ Sangat Tinggi } & \multicolumn{2}{|c|}{ Tinggi } & & \\
\hline & $\mathrm{Ha}$ & $\%$ & На & $\%$ & $\mathrm{Ha}$ & $\%$ & $\mathrm{Ha}$ & $\%$ & $\mathrm{Ha}$ & $\%$ & Ha & $\%$ \\
\hline Pekalongan Barat & 56 & 6,8 & 41 & 22,5 & 905 & 25,6 & 17 & 20,4 & 3 & 2,4 & 1.024 & 21.5 \\
\hline Pekalongan Selatan & 0 & 0 & 4 & 2,2 & 1.065 & 30,2 & 24 & 28,0 & 16 & 12,8 & 1.109 & 23.3 \\
\hline Pekalongan Timur & 0 & 0 & 11 & 6,1 & 938 & 26,6 & 21 & 24,6 & 20 & 16,1 & 990 & 20.8 \\
\hline Pekalongan Utara & 773 & 93,2 & 128 & 69,3 & 620 & 17,6 & 23 & 27,0 & 85 & 68,6 & 1.631 & 34.3 \\
\hline Total Luas & 830 & 17,5 & 185 & 3,9 & 3.530 & 74,2 & 86 & 1,8 & 124 & 2,6 & 4.756 & 100 \\
\hline
\end{tabular}

Sumber: Analisis, 2020

Jasa ekosistem penyediaan air bersih dengan kelas sangat rendah hingga rendah dominan dijumpai di sebelah utara dari Kota Pekalongan. Luasan tiap kecamatan dalam konteks penyediaan air bersih dengan kelas sangat rendah - rendah terdapat di Kelurahan Pasirsari, Kecamatan Pekalongan Barat, Kelurahan Jenggot dan Kelurahan Kertoharjo, Kecamatan Pekalongan Selatan, Kelurahan Bandengan di Kecamatan Pekalongan Utara. Luasan wilayah Kota Pekalongan dengan kelas jasa penyediaan pangan sangat rendah - rendah adalah sebesar 1.010 Ha atau setara $21 \%$ dari luas keseluruhan.

Penyediaan air bersih dengan kelas sedang terdapat di bagian tengah, memanjang dari selatan hingga ke utara mendominasi luasan keseluruhan dari Kota Pekalongan. Distribusi luasan per kecamatan untuk penyediaan air bersih dengan kelas sedang dapat dijumpai di Kelurahan Medono dan Kelurahan Tirto, Kecamatan Pekalongan Barat, Kelurahan Duwet dan Kelurahan Jenggot di Kecamatan Pekalongan Selatan. Kelurahan Gamer untuk Kecamatan Pekalongan Timur. Kelurahan Degayu, Kelurahan Krapyak Lor, dan Kelurahan Panjang Wetan di Kecamatan Pekalongan Utara. Wilayah dengan jasa ekosistem penyediaan air bersih kelas sedang memiliki luasan sebesar 3530,44 Ha atau setara dengan persentase $74,22 \%$ dari luas keseluruhan Kota Pekalongan. Informasi rinci mengenai luasan tiap kelas jasa ekosistem penyediaan air bersih di Kota Pekalongan disajikan dalam Tabel 2 dan Gambar 5.

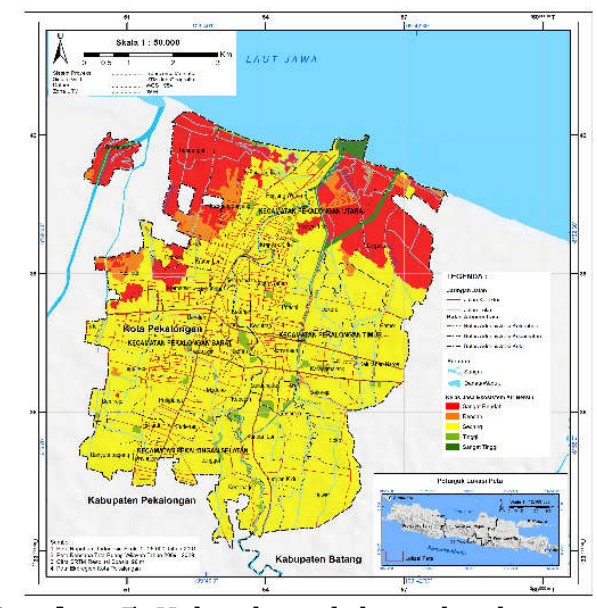

Gambar 5. Kelas daya dukung lingkungan sektor panyedia air bersih
Daya dukung lingkungan jasa ekosistem penyedia air bersih dengan kelas tinggi - sangat tinggi di Kota Pekalongan memiliki pola sebaran yang terbatas, hanya menyisip di antara wilayah dengan kelas sedang untuk penyediaan air bersih. Dari sudut pandang ekoregion, wilayah dengan kelas tinggi sangat tinggi hanya berada pada Ekoregion Dataran Fluvial. Sebaran per kelurahan dari jasa ekosistem penyediaan air bersih secara kuantitas (debit) dan kualitas, dengan kelas tinggi - sangat tinggi terdapat di Kelurahan Kebulen, Kelurahan Kergon, dan Kelurahan Pringlangu untuk Kecamatan Pekalongan Barat. Wilayah dengan jasa ekosistem penyediaan air bersih kelas tinggi - sangat tinggi memiliki luasan sebesar 210,37 Ha atau setara dengan persentase 4\% dari luas keseluruhan Kota Pekalongan.

\section{Kesimpulan}

Di daerah penelitian diperoleh hasil secara umum rendah untuk penyedia pangan dan sedang untuk penyedia air bersih. Daya dukung dengan pendekatan jasa lingkungan untuk sector penyedia pangan menujukkan hasil secara umum rendah dengan luas wilayah 47,11\% dari Kota Pekalongan. Nilai daya dukung tinggi sangat tinggi sebesar $1.239,76$ ha atau 26,06 dari luas Kota Pekalongan yang berada di bagian tenggara Kota Pekalongan. Daya Dukung dan daya tampung lingkungan hidup penyedia air bersih secara umum memiliki kemampuan sedang atau $74,22 \%$ luas Kota Pekalongan. Bagian utara yang berbatasan dengan laut Jawa menunjukkan kelas yang sangat rendah dikarenakan terjadi penurunan kulitas air akibat dari bercampurnya air tawar dan air laut.

\section{UCAPAN TERIMA KASIH}

Artikel ini merupakan salah satu bagian dengan analisis lanjut dari penelitian terkait kajian daya dukung dan daya tampung lingkungan hidup berbasis jasa ekosistem di Kota Pekalongan yang difasilitasi oleh Dinas Lingkungan Hidup (DLH) Kota Pekalongan.

\section{DAFTAR PUSTAKA}

Dinas lingkungan Hidup dan Kehutanan (DLHK) Provinsi Jawa Tengah, (2017), Informasi Kinerja Pengelolaan Lingkungan Hidup Daerah, Laporan Akhir, Pemerintah Provinsi Jawa Tengah, Semarang,

Dinas Lingkungan Hidup (DLH) Kabupaten Semarang, (2018), Daya Dukung Daya Tampung Kabupaten 
Semarang, Laporan Penelitian, Dinas Lingkungan Hidup (DLH) Kabupaten Semarang,

Dinas Lingkungan Hidup (DLH) Kota Pekalongan, (2018), Kajian Daya Dukung Daya Tampung Lingkungan Kota Pekalongan, Jawa Tengah, Laporan Penelitian, Dinas Lingkungan Hidup (DLH) Kota Pekalongan

Enrique M, and Milagros P,R, (2017), Practical Decision Making: An Introduction to the Analytic Hierarchy Process (AHP) Using Super Decisions V2 [1 ed,],SpringerBriefs in Operations Research,Springer International Publishing,

Kementerian Lingkungan Hidup (KLH), (2014), Pedoman Daya Dukung Daya Tampung Lingkungan,Kementerian Lingkungan Hidup Deputi 1 Bidang Tata Lingkungan Asisten Deputi Perencanaan Pemanfaatan SDA \& LH \& Kajian Kebijakan LH Wilayah \& Sektor: Jakarta,

Millennium Ecosystem Assessment (MEA), (2005), Ecosystems and Human Well- Being: Synthesis, Island Press, Washington, USA

Muta'ali L., (2015), Teknik Analisis Regional Untuk, Perencanaan Wilayah Tata Ruang dan Lingkungan, Yogyakarta: Badan Penerbit Fakultas Geografi,

Pusat Pengendalian Pembangunan Ekoregion Jawa (P3EJ), (2015), Peta Ekoregion Jawa Tengah, Pusat Pengendalian Pembangunan Ekoregion Jawa: Yogyakarta

Pusat Pengendalian Pembangunan Ekoregion Jawa (P3EJ), (2017), Pedoman Penggunaan Peta Daya Dukung Dan Daya Tampung Lingkungan Hidup (D3TLH), Pusat Pengendalian Pembangunan Ekoregion Jawa: Yogyakarta

Pusat Pengendalian Pembangunan Ekoregion Sumatera (P3ES), (2011), Daya Dukung Dan Daya Tampung Lingkungan Hidup Ekoregion Sumatera Berbasis Jasa Ekosistem, Pusat Pengendalian Pembangunan Ekoregion Sumatera: Pekanbaru
Republik Indonesia, (2009), Peraturan Menteri Negara Lingkugan Hidup Republik Indonesia Nomor 17 tahun 2009 tentang Pedoman Penentuan Daya Dukung Lingkungan Hidup dalam Penataan Ruang Wilayah, Deputi V MENLH Bidang Penataan Lingkungan, Jakarta,

Republik Indonesia, (2009), Undang-Undang Republik Indonesia Nomor 32 Tahun 2009 tentang Perlindungan dan Pengelolaan Lingkungan Hidup, Lembaran Negara RI Tahun 2009 Nomor 140, Sekretariat Negara, Jakarta,

Sabila S., (2020), Daya Dukung Pangan Dalam Mendukung Ketersediaan Pangan Provinsi Sumatera Selatan, Jurnal Tanah dan Sumberdaya Lahan, Vol 7 No,1:5968,2020 ,

Santosa L.W., (2010), Ekoregion sebagai Kerangka Dasar dalam Perlindungan dan Pengelolaan Lingkungan, Makalah, Disampaikan dalam seminara Nasional "Semangat Pejuangan dari Jogja: Kembalikan Indonesiaku Hijau", University Center UGM, 23 Desember 2010,

Sumadyanti U.V., Zuharnen, dan Widayani P., (2016), Monitoring Daya Dukung Lingkungan Berbasis Jasa Ekosistem (Rekreasi dan Ecotourism) Tahun 2000 dan 2015 Menggunakan Citra Landsat (Lokasi Kabupaten Badung Bagian Barat, Provinsi Bali), Jurnal Bumi Indonesia,Vol 5 No.4:1-10. 2016.

UU No.32 Tahun (2009) Tentang Perlindungan dan Pengelolaan Lingkungan Hidup, Presiden Republik Indonesia, 3 Oktober,

Widodo B., Lupyanto R., Sulistiono B., Harjito D.A., dan Hamidin J., (2015), Analysis of environmental carrying capacity for the development of sustainable settlement in Yogyakarta Urban Area, Procedia Environmental Sciences 28: 519-527, doi :10.1016/j.proenv.2015.07.062. 